\title{
Quality education for Latin American countries: analysis and contributions from the Policy on Educational Success of Québec
}

\author{
Everton da Silva Camillo \\ Ph.D. candidate and Master in Information Science; São Paulo State University, São Paulo, SP, Brazil; \\ everton.camillo@unesp.br \\ Dorothée Boccanfuso \\ Ph.D in Economic Science; Mohammed VI Polytechnic University, Benguerir, Morocco; \\ dorothee.boccanfuso@um6p.ma \\ Claudio Marcondes de Castro Filho \\ Ph.D in Information Science; São Paulo University, São Paulo, SP, Brazil; \\ claudiomarcondes@ffclro.usp.br
}

\begin{abstract}
This paper aimed at presenting recommendations on high-quality education to Latin American countries' governments by taking the Policy on Educational Success of Québec as Québec's main official document to achieve quality education. By using the content analysis method, it was investigated the extent to which the Policy on Educational Success of Québec adheres to the Sustainable Development Goal (SDG) number 4 (Quality Education), as well as it was analyzed the concordance of the most significant words from the same policy. Findings demonstrate that the Policy on Educational Success of Québec comprises acts that mostly go towards the promotion of equitable development of the people, to people's learning, skills, and competences, and to the quality in teaching and in learning processes, and in learning spaces. In contrast, the acts that are less significant in the analysis but equally fundamental for the development of society are related to the minimum conditions to achieve quality education, and to the vocational training to foster quality education. Moreover, it was comprehended that the ensuring of quality education in Latin American countries can immediately be linked to some scopes, like the student, school, service, and education ones. This paper concludes that Latin American countries' governments can support ensuring quality education for their peoples whether they give special attention to the student, school, service, and education scopes in society.
\end{abstract}

Keywords: Education Policy. 2030 Agenda. Latin America. Canada. Québec. 


\section{Introduction}

Québec's early childhood education policies have become the most significant ones in Canada and worldwide due to their impact on the integral development of children. Educational initiatives have been established based on the principals of high-quality education in the province, and the Government of Québec decided to renew the concept of success on education for the last 20 years. In this sense, the province ended up obtaining social, economic, and cultural progresses when began counting on the role of policies that assisted in impacting on children development. The Policy on Educational Success of Québec is clearly at the core of significant actions at present (CANADA, 2017).

This policy is an important one to French-Canadians due to its conception of high-quality education. It was projected over three broad areas of intervention, challenges, and orientations, and they are: (1) everyone achieving their full potential; (2) an inclusive environment for development, learning and success; and (2) the mobilization of partners and stakeholders in support of educational success.

According to the Policy, 'everyone achieving their full potential' " $[\ldots]$ is at the heart of the mission of schools and educational childcare centrers. Child development has a significant impact on preparation for school, adaptation to the school environment and educational success." (CANADA, 2017, p. 38).

By 'an inclusive environment for development, learning and success' it is meant that

[...] educational childcare centrers and schools are open environments that welcome people from a wide variety of socioeconomic, cultural and ethnic backgrounds, and where people learn about life as they meet others and discover new possibilities. (CANADA, 2017, p. 51).

With regard to the "mobilization of partners and stakeholders in support of educational success', the Policy means that "[...] education is a social responsibility that requires a shared vision of educational success in order to ensure consistent and complementary actions." (CANADA, 2017, p. 63). 
Thus far, each area of intervention of the Policy on Educational Success of Québec is a fundamental one, and they are supposed to be apprehended as interdependents. The success of interventions of one level depends on their complementarity with interventions at the other levels, and, mainly, on crucial efforts of the various practitioners, stakeholders and partners. In short, the Policy should assist children in achieving high-quality education by intervening in areas such as children and students, school and educational childcare centers, and community, stakeholders and partners. It is equally important to mention that several social agents should participate in the process of intervening. They are fundamental to achieve decisive goals in society.

To United Nations' (UN) 2030 Agenda, the term 'quality education' means an educational approach to ensure inclusive and equitable education and the promotion of lifelong learning for all (UNITED..., 2015). The Sustainable Development Goal (SDG) 4 of quality education is indispensable to paving the way to people to reach new goals in life. Equally important, SDG 4 can even help overcoming poverty and hunger and guarantying a healthier life, gender equity, access to clean water and sanitation, and qualified job opportunities (BOEREN, 2019). In agreement with Boccanfuso, Larouche, and Trandafir (2015), education is a crucial issue in a country's economy and social development. Additionally, as stated in the Comisión's report (COMISIÓN ECONÓMICA PARA AMÉRICA LATINA Y EL CARIBE, 2014), education is one of the fundamental rights of every person, as well as it is a decisive element of democratic development and citizenship in nations worldwide.

In specialized literature, Latin American countries are generally approached as developing ones. Many reasons would justify why they are considered so. Examples are their fragile development of economy, vulnerable public security systems, absence of qualified job opportunities, calamity of public health systems, asymmetric income distribution, large corruption schemes, lack of quality education for the people, and so forth.

This scientific research is placed in the field of education, thus focusing on the lack of quality education for the people in Latin America region seems appropriate. This way, as reported by Rodríguez (2019), Latin American 
countries still face some remaining challenges from the last century for the field of education, which are to guarantee proper pre-school, elementary and highschool educations, to strengthen professional education and to expand the adult one. Likewise, initiatives on including native people to formal school systems and on enhancing education methods still lack of commitment by governments.

Murillo (2016) state that Latin American countries will go through some defiant stages on providing education to their people in the twentieth-first century. Some of these issues are related to inappropriate school facilities, and unschooling process due to repeating the class or dropping out school.

All of this scenario sustains the recurring idea that Latin America is a region in the world where inequality among people still remains. Conforming to Castro, Rodríguez-Gómez and Gairín (2017), Lopez-Calva, Lustig and Ortiz Juarez (2015), and Székely and Mendoza (2017), it is widely known that Latin America is one of the most unequal regions in the world, just like sub-Saharan region in Africa. But, in contrast to the latter, issues that persist in Latin America are commonly related to income, consumption expenditures, political influence, security, health and education.

From this point on, with respect to acquiring high-quality education to the current educational setting of Latin American countries, the research question to this investigation is identified in the following: what actions can Latin American countries' governments take to provide high-quality education to their peoples?

In this paper it is presented recommendations on high-quality education to Latin American countries' governments by taking the Policy on Educational Success of Québec as Québec's main official document to achieve quality education. By using the content analysis method, it was investigated the extent to which the Policy on Educational Success of Québec adheres to the SDG number 4 , as well as it was analyzed the concordance of the most significant words from the same policy. 


\section{Methodology}

According to Bardin (2016), the content analysis is a method composed of three intrinsically related phases. They are 'pre-analysis', 'exploration of the material', and 'dealing with the results and interpretation'.

In the 'pre-analysis' phase the analyst performs the pre-analysis of corpus, that is the documents, and systematizes ideas that lead to an accurate scheme of successive operations. Then, the 'exploration of the material' phase is related to descripting significant contents from the corpus. These significant contents are named 'unit records'. But to collect them from the documents it is important to create categories, as seen in the chart 1 . So, if pre-analysis phase is successfully completed, the following procedure consists in applying some decisions over the data.

Chart 1 - Categories and indicators.

\begin{tabular}{|c|c|}
\hline Category A & People's learning, skills, and competences \\
\hline Indicator A1 & To develop effective learning. \\
\hline Indicator A2 & To develop technical skills in people due to the labor market. \\
\hline Category B & The quality in teaching and learning processes, and in learning spaces \\
\hline Indicator B1 & To obtain early childhood and pre-school educations. \\
\hline Indicator B2 & To achieve technical, vocational and higher educations to adults. \\
\hline Indicator B3 & To construct and improve places to develop education for all. \\
\hline Category $\mathbf{C}$ & The promotion of equitable development of the people \\
\hline Indicator $\mathrm{C} 1$ & To eliminate gender inequality and prejudices from the field of education. \\
\hline Indicator $\mathrm{C} 2$ & $\begin{array}{l}\text { To acquire knowledge and skills to ensure global citizenship, } \\
\text { sustainability, human rights and cultural diversity. }\end{array}$ \\
\hline Category D & The minimum conditions to achieve quality education \\
\hline Indicator D1 & To ensure literacy and basic mathematics for the people. \\
\hline Category E & The vocational training to foster quality education \\
\hline Indicator E1 & To access scholarships and vocational training programs. \\
\hline Indicator E2 & To increase the number of qualified teachers and teacher's trainings. \\
\hline
\end{tabular}
Source: survey data.

The categories and indicators were created based on the UN's 2030 Agenda SDG 4 and its ten goals. To UN (UNITED..., 2020), they are:

a) By 2030, ensure that all girls and boys complete free, equitable, and quality primary and secondary education leading to relevant and effective learning outcomes;

b) By 2030, ensure that all girls and boys have access to quality early childhood development, care and pre-primary education so that they are ready for primary education; 
c) By 2030, ensure equal access for all women and men to affordable and quality technical, vocational and tertiary education, including university;

d) By 2030, substantially increase the number of youth and adults who have relevant skills, including technical and vocational skills, for employment, decent jobs and entrepreneurship;

e) By 2030, eliminate gender disparities in education and ensure equal access to all levels of education and vocational training for the vulnerable, including persons with disabilities, indigenous peoples and children in vulnerable situations;

f) By 2030, ensure that all youth and a substantial proportion of adults, both men and women, achieve literacy and numeracy;

g) By 2030, ensure that all learners acquire the knowledge and skills needed to promote sustainable development, including, among others, through education for sustainable development and sustainable lifestyles, human rights, gender equality, promotion of a culture of peace and nonviolence, global citizenship and appreciation of cultural diversity and of culture's contribution to sustainable development;

h) Build and upgrade education facilities that are child, disability and gender sensitive and provide safe, non-violent, inclusive and effective learning environments for all;

i) By 2020, substantially expand globally the number of scholarships available to developing countries, in particular least developed countries, small island developing States and African countries, for enrolment in higher education, including vocational training and information and communications technology, technical, engineering and scientific programmes, in developed countries and other developing countries;

j) By 2030, substantially increase the supply of qualified teachers, including through international cooperation for teacher training in developing countries, especially least developed countries and small island developing States.

The systematization of the record units of the Policy on Education Success of Québec is seen in the chart 2. 
Chart 2 - The systematization of record units.

\begin{tabular}{|c|c|c|}
\hline CATEGORIES & INDICATORS & UNIT RECORDS \\
\hline Category A & Indicator A1 & \multirow[b]{2}{*}{$\begin{array}{l}\text { "[...] study the possibility of extending } \\
\text { the age of compulsory schoo] } \\
\text { attendance from } 16 \text { to } 18 \text {, or until the } \\
\text { student has obtained a first diploma or } \\
\text { qualification, by offering educational } \\
\text { paths that meet their needs, particularly } \\
\text { in training for qualifications". } \\
\text { "[...] launch an action plan concerning } \\
\text { digital technologies in education, } \\
\text { higher education and competency } \\
\text { development". } \\
\text { "[...] work toward the modernization } \\
\text { of pedagogical frameworks and } \\
\text { procedures for the evaluation of } \\
\text { learning.". } \\
\text { "[...] publish a broad plan of action to } \\
\text { diversify and adapt educational } \\
\text { services and offer the necessary } \\
\text { guidance so that all students, regardless } \\
\text { of their needs or social background, } \\
\text { can achieve their full potential.". } \\
\text { "[...] implement the conditions needed } \\
\text { to offer a stimulating school } \\
\text { environment based on best practices } \\
\text { and the most successful models.". }\end{array}$} \\
\hline \multirow[t]{3}{*}{$\begin{array}{l}\text { People's learning, skills, } \\
\text { and competences. }\end{array}$} & $\begin{array}{l}\text { To develop effective } \\
\text { learning. }\end{array}$ & \\
\hline & Indicator A2 & "[...] fostering equal opportunity and \\
\hline & $\begin{array}{l}\text { To develop technical } \\
\text { skills in people due to the } \\
\text { labor market. }\end{array}$ & $\begin{array}{l}\text { providing a framework for home } \\
\text { schooling and free schooling for } \\
\text { students with precarious immigration } \\
\text { status, and bestowing more powers on } \\
\text { institutions offering young people } \\
\text { educational services outside the current } \\
\text { frameworks.". } \\
\text { "[...] the government will open up } \\
\text { dialogue with the business community } \\
\text { to solicit its involvement beyond } \\
\text { adapting vocational training to labour } \\
\text { market needs and make companies } \\
\text { aware of the importance of educational } \\
\text { success.". } \\
\text { "[...] the government will encourage } \\
\text { the promotion and continued presence } \\
\text { in schools at the local, regional and } \\
\text { provincial levels of models of } \\
\text { educational and professional success.". }\end{array}$ \\
\hline Category B & Indicator B1 & "[...] continue the implementation of \\
\hline $\begin{array}{l}\text { The quality in teaching } \\
\text { and learning processes, } \\
\text { and in learning spaces. }\end{array}$ & $\begin{array}{l}\text { To obtain early } \\
\text { childhood and pre-school } \\
\text { educations. }\end{array}$ & $\begin{array}{l}\text { full-time kindergarten for } 4 \text {-year-olds } \\
\text { to complement educational childcare } \\
\text { centre services.". }\end{array}$ \\
\hline
\end{tabular}




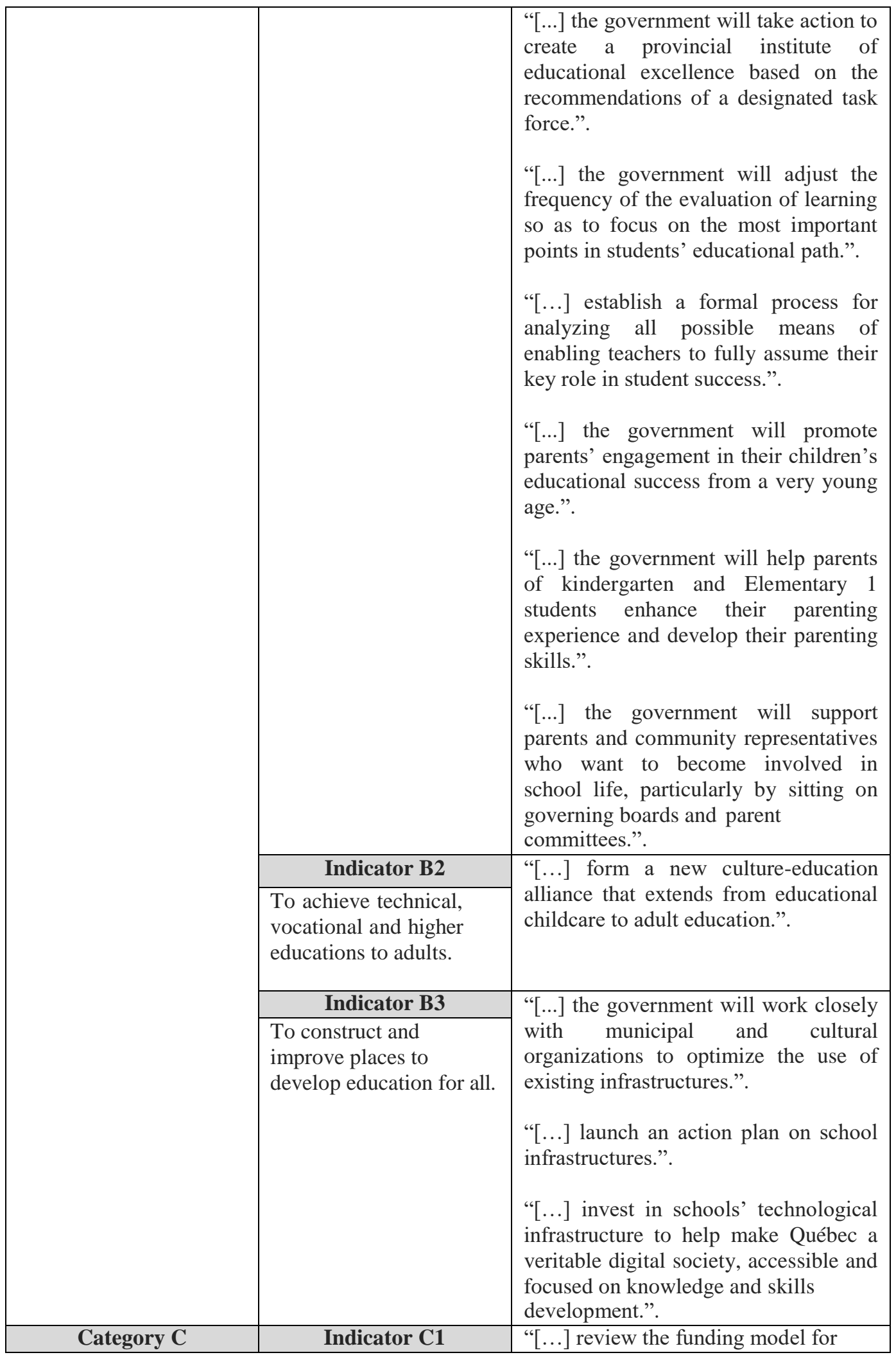




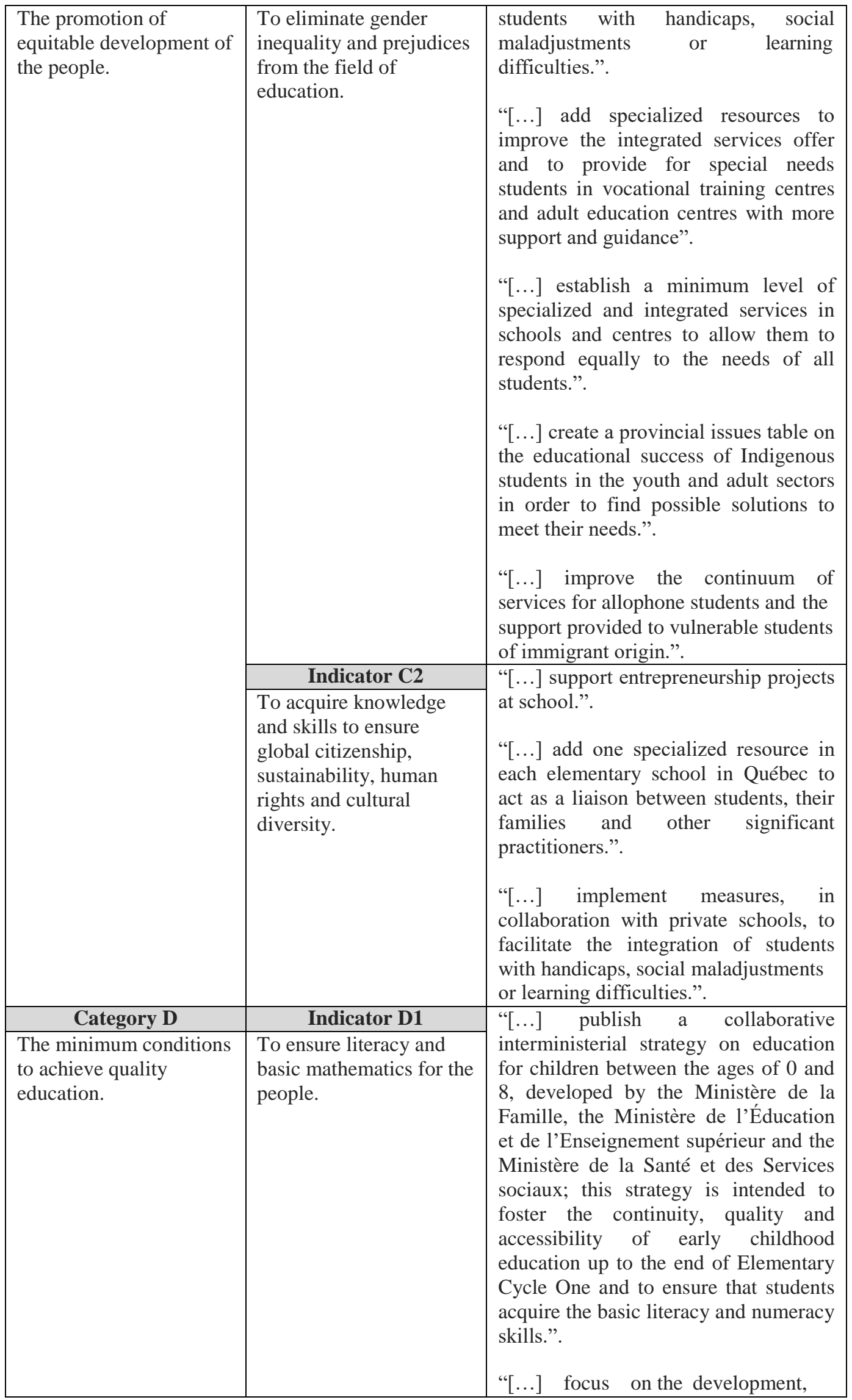




\begin{tabular}{|c|c|c|}
\hline & & $\begin{array}{l}\text { enhancement and maintenance of } \\
\text { literacy skills throughout life, in } \\
\text { particular by implementing a literacy } \\
\text { and francization strategy and } \\
\text { implementing a strategy to improve } \\
\text { language skills.". }\end{array}$ \\
\hline Category E & Indicator E1 & \multirow{2}{*}{$\begin{array}{l}\text { "[...] launch a vocational training } \\
\text { action plan.". }\end{array}$} \\
\hline \multirow[t]{3}{*}{$\begin{array}{l}\text { The vocational training } \\
\text { to foster quality } \\
\text { education. }\end{array}$} & $\begin{array}{l}\text { To access scholarships } \\
\text { and vocational training } \\
\text { programs. }\end{array}$ & \\
\hline & Indicator E2 & \multirow[b]{2}{*}{$\begin{array}{l}\text { "[...] launch a major initiative on the } \\
\text { valorization of the teaching profession } \\
\text { and the professional autonomy of } \\
\text { teachers.". } \\
\text { "[...] in collaboration with the school } \\
\text { system and the university community, } \\
\text { publish a new competencies framework } \\
\text { for the teaching profession aiming to } \\
\text { update initial teacher training and } \\
\text { professional development for teacher". } \\
\text { "[...] create an annual prize to be } \\
\text { awarded to a teacher in recognition of } \\
\text { his or her innovative pedagogical } \\
\text { practices.". }\end{array}$} \\
\hline & $\begin{array}{l}\text { To increase the number } \\
\text { of qualified teachers and } \\
\text { teacher's trainings. }\end{array}$ & \\
\hline
\end{tabular}

Source: survey data.

The phase 'dealing with the results and interpretation' is the last one of the content analysis method. At this stage, the analyst performs interpretations. And some figures, charts, and graphics can be composed in order to achieve the research goal by responding the research question.

In addition, a lexical analysis was performed. This is a technique that consists in measuring the quantity of words of the corpus, and it also aims at recognizing the lexical base of the documents to allow the analyst to state on what he/she observes when dealing with the data for interpretations to begin.

The online tool Word Cloud Art Creator assisted in representing the frequency of words, and the software Orange, for data mining, enabled doing a concordance analysis.

\section{Results and discussions}

The significant unit records from The Policy on Educational Success of Québec were analyzed by density. The first density, seen in the graphic 1 , is on the categories, and the second one is on the indicators. 
Graphic 1 - The density of the categories.

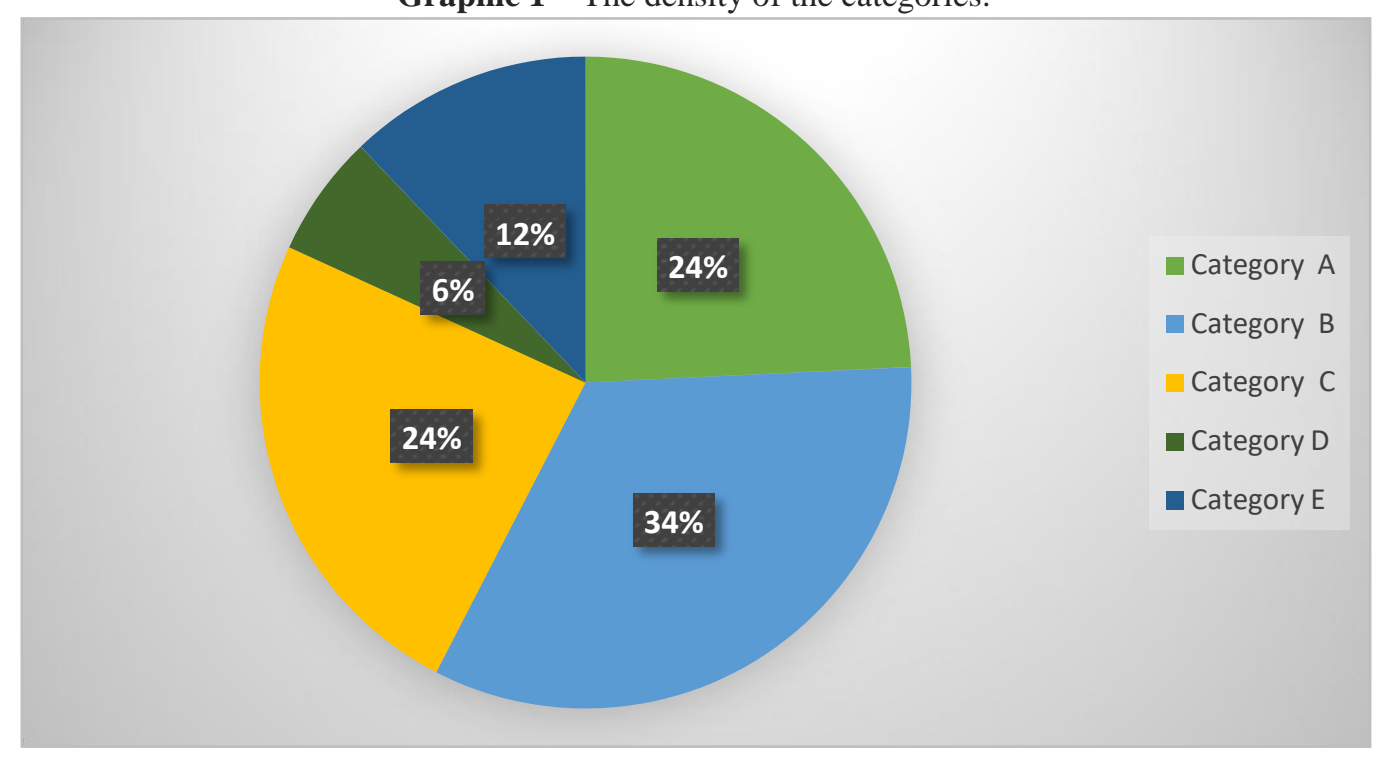

Source: survey data.

The density of the Category B (The quality in teaching and learning processes, and in learning spaces) is $34 \%$, then, the highest one. Subsequently, the Category A (People's learning, skills, and competences) holds the secondhighest value, $24 \%$, as long as the Category C (The promotion of equitable development of the people) also holds $24 \%$.

Next, the density of the Category D (The minimum conditions to achieve quality education) is $6 \%$. And to conclude, the Category $\mathrm{E}$ (The vocational training to foster quality education) holds $12 \%$.

The resolution of the mathematical formula resulted in

an average value of 6.6. This way, now it is possible to frame the categories that are placed above and below the average value, as the figure 1 demonstrates. 
Figure 1 - The categories placed above and below the average value.

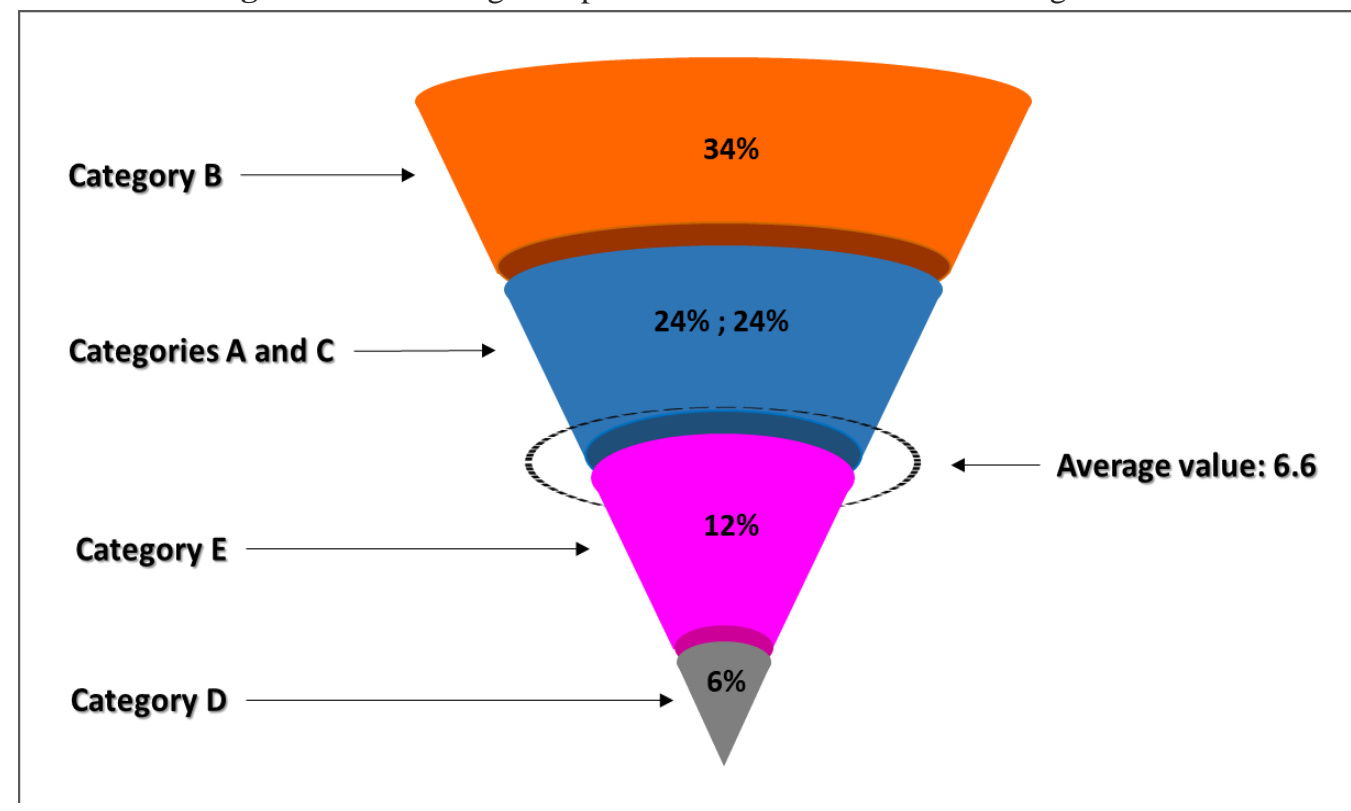

Source: survey data.

The Categories $\mathrm{A}, \mathrm{B}$ and $\mathrm{C}$ are all placed above the average value because their number of unit records by each category was 8,11 and 8 , respectively. However, the Category $B$ is the most significant one. Its indicators hold, together, 11 unit records, but not equally divided. They are the Indicators B1 (To obtain early childhood and pre-school educations), B2 (To achieve technical, vocational and higher educations to adults), and B3 (To construct and improve places to develop education for all).

In the Category A, the Indicators A1 (To develop effective learning) and A2 (To develop technical skills in people due to the labor market) hold 8 unit records together. The same value was registered to the Category $\mathrm{C}$. It also holds 8 unit records, which are placed into its two indicators: Indicator C1 (To eliminate gender inequality and prejudices from the field of education) and Indicator C2 (To acquire knowledge and skills to ensure global citizenship, sustainability, human rights and cultural diversity).

Opposing, the Categories D and E were placed below the average value. The reason is because their number of unit records by each category was 2 and 4 , respectively. Both of them are below the average value of 6.6. Their indicators are 'To ensure literacy and basic mathematics for the people' (Category D), and 'To access scholarships and vocational training programs' 
and 'To increase the number of qualified teachers and teacher's trainings' (Category E).

The major interventions of the Policy on Educational Success of Québec are related to the quality in teaching and learning processes, and in learning spaces (Category B). As read in this Policy (CANADA, 2017), the Government of Québec will "[...] continue the implementation of full-time kindergarten for 4-year-olds to complement educational childcare centre services." (CANADA, 2017, p. 41). Also, it will "[...] take action to create a provincial institute of educational excellence based on the recommendations of a designated task force." (CANADA, 2017, p. 55), “[...] adjust the frequency of the evaluation of learning so as to focus on the most important points in students' educational path.” (CANADA, 2017, p. 55), “[...] establish a formal process for analyzing all possible means of enabling teachers to fully assume their key role in student success.” (CANADA, 2017, p. 55), “[...] promote parents' engagement in their children's educational success from a very young age." (CANADA, 2017, p. 66), and "[...] help parents of kindergarten and Elementary 1 students enhance their parenting experience and develop their parenting skills." (CANADA, 2017, p. 66).

Still, other commitments of the Government of Québec to people are related to supporting "[...] parents and community representatives who want to become involved in school life, particularly by sitting on governing boards and parent committees." (CANADA, 2017, p. 66), to forming "[...] a new cultureeducation alliance that extends from educational childcare to adult education." (CANADA, 2017, p. 59), to working “[...] closely with municipal and cultural organizations to optimize the use of existing infrastructures." (CANADA, 2017, p. 62), to launching “[...] an action plan on school infrastructures." (CANADA, 2017 , p. 62), and to investing “[...] in schools' technological infrastructure to help make Québec a veritable digital society, accessible and focused on knowledge and skills development." (CANADA, 2017, p. 62).

In addition, other intentions of this government that are related to people's learning, skills, and competences are to 
[...] study the possibility of extending the age of compulsory school attendance from 16 to 18 , or until the student has obtained a first diploma or qualification, by offering educational paths that meet their needs, particularly in training for qualifications (CANADA, 2017, p. 41),

to "[...] launch an action plan concerning digital technologies in education, higher education and competency development." (CANADA, 2017, p. 46), to "[...] work toward the modernization of pedagogical frameworks and procedures for the evaluation of learning." (CANADA, 2017, p. 46), to

[...] publish a broad plan of action to diversify and adapt educational services and offer the necessary guidance so that all students, regardless of their needs or social background, can achieve their full potential (CANADA, 2017, p. 50),

to "[...] implement the conditions needed to offer a stimulating school environment based on best practices and the most successful models." (CANADA, 2017, p. 59), and to foster

[...] equal opportunity and providing a framework for home schooling and free schooling for students with precarious immigration status, and bestowing more powers on institutions offering young people educational services outside the current frameworks (CANADA, 2017, p. 50).

Still, other actions are linked with people's learning, skills, and competences. They are related to opening up "[...] dialogue with the business community to solicit its involvement beyond adapting vocational training to labour market needs and make companies aware of the importance of educational success." (CANADA, 2017, p. 70) and to encouraging "[...] the promotion and continued presence in schools at the local, regional and provincial levels of models of educational and professional success." (CANADA, 2017, p. 70).

The Category $\mathrm{C}$, on the promotion of equitable development of the people, holds some discourses for the Government of Québec to achieve in the upcoming years. According to the Policy on Educational Success of Québec (CANADA, 2017), the government will "[...] review the funding model for students with handicaps, social maladjustments or learning difficulties." 
(CANADA, 2017, p. 41), “[...] add specialized resources to improve the integrated services offer and to provide for special needs students in vocational training centres and adult education centres with more support and guidance." (CANADA, 2017, p. 41), “[...] establish a minimum level of specialized and integrated services in schools and centres to allow them to respond equally to the needs of all students." (CANADA, 2017, p. 50), and "[...] create a provincial issues table on the educational success of Indigenous students in the youth and adult sectors in order to find possible solutions to meet their needs." (CANADA, 2017, p. 50).

Other important actions are connected to the proposal of improving “[...] the continuum of services for allophone students and the support provided to vulnerable students of immigrant origin." (CANADA, 2017, p. 50), of supporting “[...] entrepreneurship projects at school." (CANADA, 2017, p. 46), of adding "[...] one specialized resource in each elementary school in Québec to act as a liaison between students, their families and other significant practitioners." (CANADA, 2017, p. 50), and of implementing "[...] measures, in collaboration with private schools, to facilitate the integration of students with handicaps, social maladjustments or learning difficulties." (CANADA, 2017, p. $50)$.

The Category E, on the vocational training to foster quality education, is part of those placed below the average value of 6.6. Its content demonstrates that the Government of Québec will "[...] launch a vocational training action plan." (CANADA, 2017, p. 46) and "[...] a major initiative on the valorization of the teaching profession and the professional autonomy of teachers." (CANADA, 2017, p. 55). Also, "In collaboration with the school system and the university community, [it will] publish a new competencies framework for the teaching profession aiming to update initial teacher training and professional development for teacher." (CANADA, 2017, p. 55, our addition) and "[...] create an annual prize to be awarded to a teacher in recognition of his or her innovative pedagogical practices." (CANADA, 2017, p. 55).

The Category $\mathrm{D}$ is on the minimum conditions to achieve quality education. It is the last category placed below the average value. Anyhow, it 
also holds discourses on action for the Government of Québec to achieve. These discourses say that the government will

[...] publish a collaborative interministerial strategy on education for children between the ages of 0 and 8 , developed by the Ministère de la Famille, the Ministère de l'Éducation et de l'Enseignement supérieur and the Ministère de la Santé et des Services sociaux; this strategy is intended to foster the continuity, quality and accessibility of early childhood education up to the end of Elementary Cycle One and to ensure that students acquire the basic literacy and numeracy skills (CANADA, 2017, p. 41)

and "[...] focus on the development, enhancement and maintenance of literacy skills throughout life, in particular by implementing a literacy and francization strategy and implementing a strategy to improve language skills." (CANADA, 2017, p. 46).

Therefore, the Policy on Educational Success of Québec comprises acts that mostly go towards the promotion of equitable development of the people, to people's learning, skills, and competences, and to the quality in teaching and in learning processes, and in learning spaces. Specifically, the actions on these themes are related to developing effective learning and technical skills in people due to the labor market, to obtaining early childhood and pre-school educations, to achieving technical, vocational and higher educations to adults, to constructing and improving places to develop education for all, to eliminating gender inequality and prejudices from the field of education, and to acquiring knowledge and skills to ensure global citizenship, sustainability, human rights and cultural diversity.

On the other hand, other actions of this policy concern to the intentions that are less significant in the Policy, but equally important to the FrenchCanadian people. They concern to the minimum conditions to achieve quality education, and to the vocational training to foster quality education. Their specific actions are to ensure literacy and basic mathematics for the people, to access scholarships and vocational training programs, and to increase the number of qualified teachers and teacher's trainings.

The lexical analysis performed revealed the most frequent terms of the Policy. They are seen in the figure 2 . 
Figure 2 - The significant words from the Policy on Educational Success of Québec

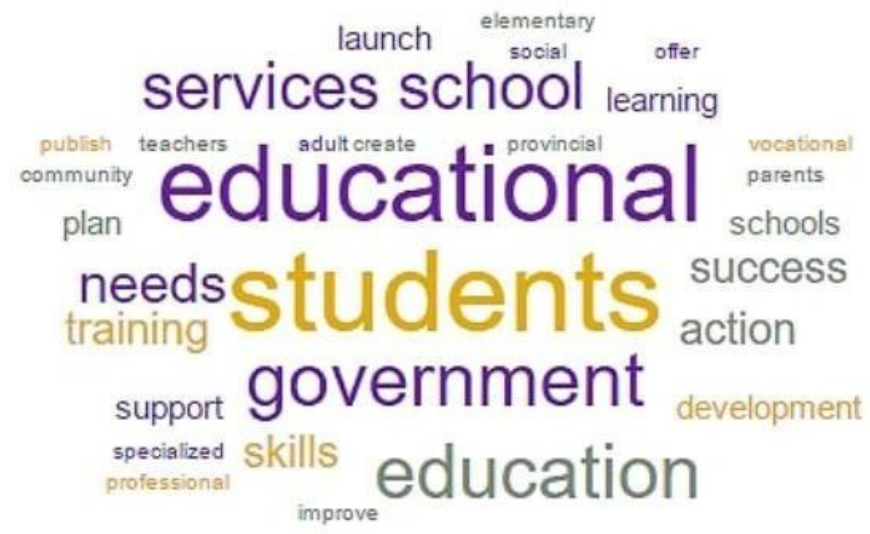

Source: survey data.

Although the figure 2 illustrates a word cloud composed with many words, the most prominent ones are 'students', 'educational', 'government', 'education', 'services' and 'school'. The different size of each word states their relevance in the Policy. Then, the bigger a word is, the most significant it is for the document as well.

Specifically, the figure 3 shows the concordance on the first word: students.

Figure 3 - The concordance on the noun 'students'

\begin{tabular}{|c|c|c|c|}
\hline 1 & the most important points in & students & 'educational path \\
\hline 2 & of kindergarten and Elementary 1 & students & enhance their parenting experience and \\
\hline 3 & Review the funding model for & students & with handicaps, social maladjustments \\
\hline 4 & offer and provide special needs & students & in vocational training centres and \\
\hline 5 & to the needs of all & students & \\
\hline 6 & the educational success of Indigenous & students & in the youth and adult \\
\hline 7 & continuum of services for allophone & students & and the support provided to \\
\hline 8 & the support provided to vulnerable & students & of immigrant origin \\
\hline 9 & act as a liaison between & students & , their families and other \\
\hline 10 & to facilitate the integration of & students & with handicaps, social maladjustments \\
\hline 11 & One and to ensure that & students & acquire the basic literacy and \\
\hline 12 & necessary guidance so that all & students & , regardless of their needs \\
\hline 13 & schooling and free schooling for & students & with precarious immigration status, \\
\hline
\end{tabular}

Source: survey data. 
The noun 'students' appears 13 times in the analysis. And its relations with other words are numerous. Basically, the statements refer to student's educational path, parenting experience, special needs, vocational trainings, development in life, origins, families, knowledge and skills.

The next concordance is on the adjective 'educational'. Its frequency number is 11 .

Figure 4 - The concordance on the adjective 'educational'

\begin{tabular}{|lrll|}
\hline $\mathbf{1}$ & or qualification , by offering & educational & paths that meet their needs \\
$\mathbf{2}$ & create a provincial institute of & educational & excellence based on the recommendations \\
$\mathbf{3}$ & important points in students ' & educational & path \\
$\mathbf{4}$ & in their children 's & educational & success from a very young \\
$\mathbf{5}$ & education alliance that extends from & educational & childcare to adult education \\
$\mathbf{6}$ & provincial issues table on the & educational & success of Indigenous students in \\
$\mathbf{7}$ & action to diversify and adapt & educational & services and offer the necessary \\
$\mathbf{8}$ & on institutions offering young people & educational & services outside the current frameworks \\
$\mathbf{9}$ & aware of the importance of & educational & success \\
10 & provincial levels of models of & educational & and professional success \\
$\mathbf{1 1}$ & year - olds to complement & educational & childcare centre services \\
& & & \\
\hline
\end{tabular}

Source: survey data.

The statements clarify that 'educational' is related to the success of the French-Canadian students from chilcare, to pre-school, elementary and highschool educations. Then, these statements concern to educational path, excellence, success, childcare, and services.

Moreover, the figure 5 delineates the concordance on the noun 'government'.

Figure 5 - The concordance on the noun 'government'

\begin{tabular}{|c|c|c|c|}
\hline 1 & the & government & will take action to create \\
\hline 2 & the & government & will adjust the frequency of \\
\hline 3 & the & government & will promote parents ' engagement \\
\hline 4 & the & government & will help parents of kindergarten \\
\hline 5 & the & government & will support parents and community \\
\hline 6 & the & government & will work closely with municipal \\
\hline 7 & the & government & will open up dialogue with \\
\hline 8 & the & government & will encourage the promotion and \\
\hline
\end{tabular}

Source: survey data. 
The number of frequencies of the noun 'government' is 8 . They all concern to the activities that need to be achieved by the Government of Québec. In addition, they are activities that aim at creating a provincial institute of education, at adjusting the frequency of learning assessment, at helping, supporting and promoting parental engagement in the education process, at working closely with cultural organizations, at opening a dialogue with commerce and at promoting models of education and education professionals' success.

On the other hand, the figure 6 presents the concordance on the noun 'education'.

Figure 6 - The concordance on the noun 'education'

\begin{tabular}{|lrlll|}
\hline $\mathbf{1}$ & & Form a new culture - & education & alliance that extends from educational \\
$\mathbf{2}$ & from educational childcare to adult & education & \\
$\mathbf{3}$ & plan concerning digital technologies in & education & , higher education and competency \\
4 & technologies in education, higher & education & and competency development \\
$\mathbf{5}$ & vocational training centres and adult & education & centres with more support and \\
$\mathbf{6}$ & a collaborative interministerial strategy on & education & for children between the ages \\
7 & and accessibility of early childhood & education & up to the end of \\
\hline & & & \\
\hline
\end{tabular}

Source: survey data.

The number of frequencies of the noun 'education' is 7 , and it denotes different importances. The discourses stated are on the establishment of alliances between culture and education, on the implementation of actions related to digital technologies, on the development of competences in higher education, on the implementation of vocational training centers, on the interministerial collaboration for the education for children between 0 and 8 -yearsold, and on the continuity and accessibility of early childhood education.

The next figure, that is the number 7 , presents the concordance on the noun 'services'. 
Figure 7 - The concordance for the noun 'services'

\begin{tabular}{|rrll|}
\hline 1 & resources to improve the integrated & services & offer and provide special needs \\
2 & level of specialized and integrated & services & in schools and centres to \\
3 & Improve the continuum of & services & for allophone students and the \\
4 & de la Santé et des & Services & sociaux; this strategy is \\
$\mathbf{5}$ & to diversify and adapt educational & services & and offer the necessary guidance \\
$\mathbf{6}$ & institutions offering young people educational & services & outside the current frameworks \\
7 & to complement educational childcare centre & services & \\
& & & \\
& & &
\end{tabular}

Source: survey data.

The number of frequencies of the noun 'services' is 7 . In the analysis, it is related to many other words that express some concerns when it comes to French-Canadian people. So, by 'services', the Policy means including specialized resources to improve the provision of integrated services to students with special needs, establishing specialized and integrated services in schools and centers to support students, improving ongoing student services and supporting immigrant ones, provisioning social services, adapting educational services, empowering institutions that provide education services, and complementing youth service centers for child education.

To conclude, the next concordance is on the noun 'school', that appears 7 times in the analysis.

Figure 8 - The concordance for the noun 'school'

\begin{tabular}{|lrll|}
\hline $\mathbf{1}$ & extending the age of compulsory & school & attendance from 16 to 18 \\
$\mathbf{2}$ & want to become involved in & school & life, particularly by sitting \\
$\mathbf{3}$ & Launch an action plan on & school & infrastructures \\
$\mathbf{4}$ & Support entrepreneurship projects at & school & \\
$\mathbf{5}$ & specialized resource in each elementary & school & in Québec to act as \\
$\mathbf{6}$ & In collaboration with the & school & system and the university community \\
$\mathbf{7}$ & needed to offer a stimulating & school & environment based on best practices \\
& & & \\
\hline
\end{tabular}

Source: survey data.

In the last concordance analysis, the term 'school' is related to 7 sentences. All of them disclose numerous discourses. They are concerned to increasing compulsory school age from 16 to 18 years old, to supporting parents and community representatives who wish to get involved in school life, to launching action plans for school infrastructure, to supporting school 
entrepreneurship projects, to creating a core in primary school for the families and education professionals, to publishing a new competency framework for education professionals, and to providing a stimulating school environment based on good practices and successful education models.

Then, the figure 9 demonstrates how Latin American countries' governments can support ensuring quality education for their peoples. In brief, relationships were made between the Categories A, B, C, D and E and the previous concordance analysis made.

Figure 9 - How Latin American countries' governments can support ensuring quality education for their peoples

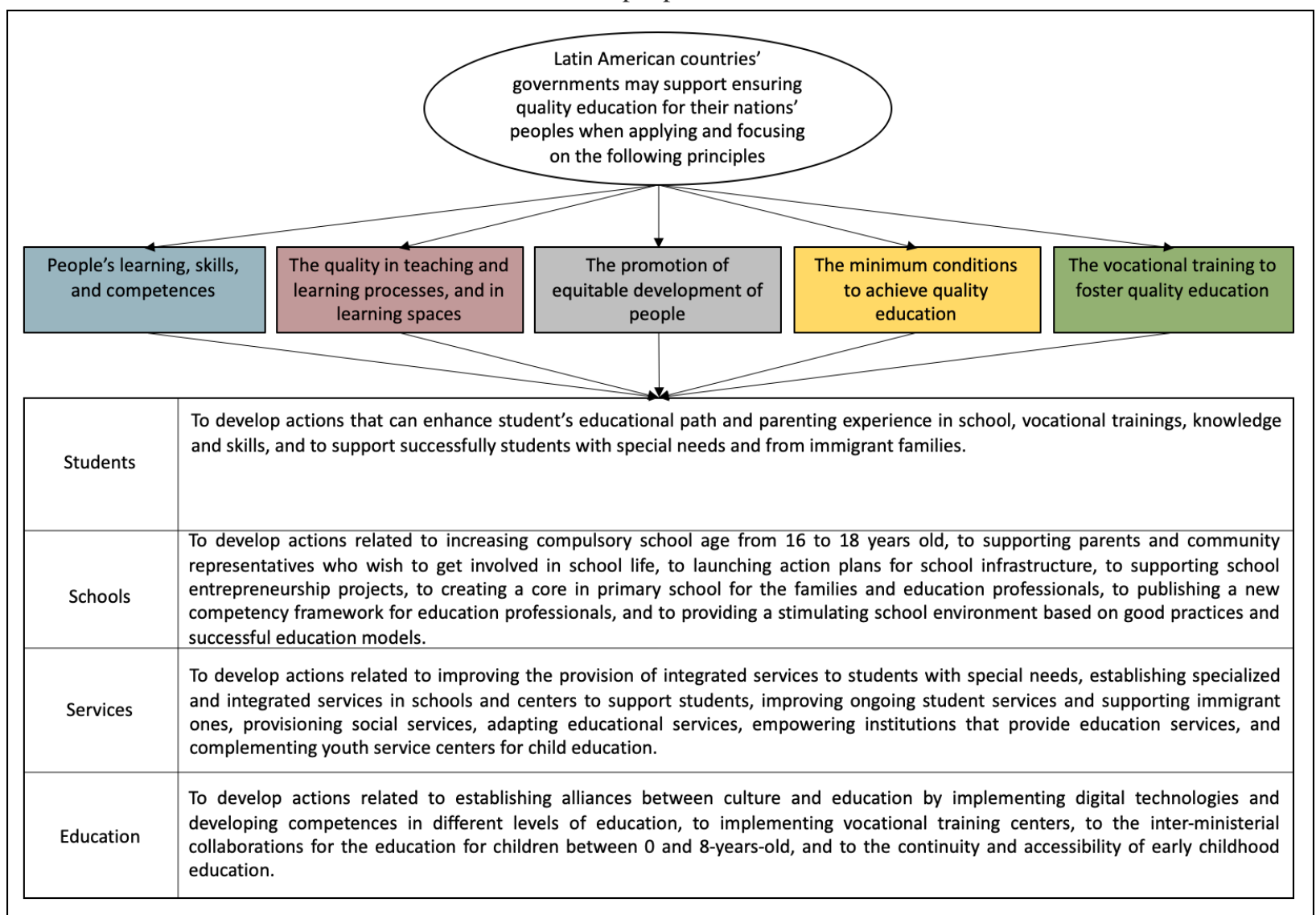

Source: survey data.

As seen in the previous figure, Latin American countries' governments can support ensuring quality education for their nations' peoples when applying and focusing on principles like people's learning, skills, and competences, the quality in teaching and learning processes, and in learning spaces, the promotion 
of equitable development of the people, the minimum conditions to achieve quality education, and the vocational training to foster quality education.

The focus on fostering high-quality education for the people can firstly be related to promoting the students' skills, schools, education services and education methods and actions. This way, Latin American countries' governments can take efforts in order to set new initiatives in society to establishing more justice, equity and quality in the educational setting.

Then, when considering the students' scope, some of the results to be achieved in Latin American countries might be the enhancement of student's educational path and parenting experience in school, as well as their vocational trainings, knowledge and skills, and support to those ones who have special needs and are from immigrant families.

Now in the school scope, some of the results can be related to increasing compulsory school age from 16 to 18 years old, to supporting parents and community representatives who wish to get involved in school life, to launching action plans for school infrastructure, to supporting school entrepreneurship projects, to creating a core in primary school for the families and education professionals, to publishing a new competency framework for education professionals, and to providing a stimulating school environment based on good practices and successful education models.

When it comes to services, other results may be related to improving the provision of integrated services to students with special needs, establishing specialized and integrated services in schools and centers to support students, improving ongoing student services and supporting immigrant ones, provisioning social services, adapting educational services, empowering institutions that provide education services, and complementing youth service centers for child education.

The last scope is the education one. It comprises education methods and actions. So, its results to Latin American countries can be related to establishing alliances between culture and education by implementing digital technologies and developing competences in different levels of education, to implementing vocational training centers, to the inter-ministerial collaborations for the 
education for children between 0 and 8-years-old, and to the continuity and accessibility of early childhood education.

\section{Conclusions}

This paper aimed at presenting recommendations on high-quality education to Latin American countries' governments by taking the Policy on Educational Success of Québec as Québec's main official document to achieve quality education.

It was demonstrated that the Policy on Educational Success of Québec comprises acts that mostly go towards the promotion of equitable development of the people, to people's learning, skills, and competences, and to the quality in teaching and in learning processes, and in learning spaces. In contrast, the acts that are less significant in the analysis but equally fundamental for the development of society are related to the minimum conditions to achieve quality education, and to the vocational training to foster quality education.

Moreover, it was comprehended that the ensuring of quality education in Latin American countries can immediately be linked to some scopes, like the student, school, service, and education ones.

As it was shown in the beginning of this paper, in Latin American countries there still have remaining issues to be solved when it comes to providing quality education for the people. Notwithstanding, the research finding demonstrates how Latin American countries' governments can support ensuring quality education for their peoples whether they give special attention to the student, school, service, and education scopes in society.

\section{Funding}

Federal Government of Canada. Gouvernement Fédéral du Canada. Coordenação de Aperfeiçoamento de Pessoal de Nível Superior (CAPES). 


\section{References}

BARDIN, L. Análise de conteúdo. São Paulo: Edições 70, 2016.

BOCCANFUSO, D.; LAROUCHE, A.; TRANDAFIR, M. Quality of higher education and the labor market in developing countries: evidence from an education reform in Senegal. World Development, Bonn, v. 74, p. 412-424, 2015.

BOEREN, E. Understanding Sustainable Development Goal (SDG) 4 "quality education" from micro, meso and macro perspectives. Internation Review of Education, [s.1], v. 65, p. 277-294, 2019.

CANADA. Gouvernement du Québec. Ministère de l'Éducation et de 1'Enseignement supérieur. Policy on Educational Success: a love of learning, a chance to succeed. Quebéc: Ministère de l'Éducation et de l'Enseignement supérieur, 2017.

CASTRO, D.; RODRÍGUEZ-GÓMEZ, D.; GAIRÍN, J. Exclusion factors in Latin American higher education: a preliminary analyze from University Governing Board Perspective. Education and Urban Society, [s.l.], v. 49, n. 2, p. 229-247, 2017.

COMISIÓN ECONÓMICA PARA AMÉRICA LATINA Y EL CARIBE. El analfabetismo funcional en América Latina y el Caribe: panorama y principales desafios de política. Santiago: Naciones Unidas, 2014.

LOPEZ-CALVA, L. F; LUSTIG, N.; ORTIZ-JUAREZ, E. A Long-Term Perspective on Inequality and Human Development in Latin America. Journal of Human Development and Capabilities, [s.l.], v. 16, n. 3, p. 319-323, 2015.

MURILLO, F. J. Midiendo la segregación escolar en América Latina. Un análisis metodológico utilizando el TERCE. REICE. Revista Iberoamericana sobre Calidad, Eficacia y Cambio en Educación, Madri, v. 14, n. 4, p. 33-60, 2016.

RODRÍGUEZ, M. L. Problemas y limitaciones de la educación en América Latina. Un estúdio comparado. Foro de Educación, Salamanca, v. 17, n. 27, p. 229-251, 2019.

SZÉKELY, M.; MENDOZA, P. Declining inequality in Latin America: structural shift or temporary phenomenon?. Oxford Development Studies, [s.l.] v. 45, n. 2, p. 204-221, 2017.

UNITED NATIONS. Transforming our world: the 2030 Agenda for the Sustainable Development. [S.l.: s.d], 2015. 
UNITED NATIONS. Sustainable Development Goals. Quality Education, [S.1.: s.d], 2020.

\title{
Educação de qualidade para países da América Latina: análise e contribuições da Política para o Sucesso Educacional do Québec
}

\begin{abstract}
Resumo: Este estudo teve como objetivo apresentar recomendações sobre a educação de qualidade aos governos dos países da América Latina, adotando a Política de Sucesso Educacional de Québec como o principal documento oficial dessa província para alcançar educação de qualidade. Utilizando o método de análise de conteúdo, investigou-se em que medida a Política de Sucesso Educacional do Québec se adere ao Objetivo de Desenvolvimento Sustentável (ODS) número 4 (Educação de Qualidade), bem como analisou-se a concordância das palavras mais significativas da mesma política. $\mathrm{O}$ resultado demonstra que a Política de Sucesso Educacional de Québec compreende atos que se destinam principalmente à promoção do desenvolvimento equitativo das pessoas, ao aprendizado, habilidades e competências das pessoas e à qualidade no ensino e nos processos de aprendizagem e nos espaços de aprendizagem. Em contrapartida, os atos menos significativos na análise, mas igualmente fundamentais para o desenvolvimento da sociedade, estão relacionados às condições mínimas para alcançar uma educação de qualidade e à formação profissional para promover educação de qualidade. Além disso, foi compreendido que a garantia da educação de qualidade nos países latinoamericanos pode estar imediatamente ligada a alguns âmbitos, como os dos estudantes, da escola, da prestação de serviços e da educação. O estudo conclui que os governos dos países da América Latina podem apoiar a garantia da educação de qualidade para seus povos se conferirem atenção especial aos alunos, à escola, aos serviços e à educação na sociedade.
\end{abstract}

Palavras-chave: Política de Educação. Agenda 2030. América Latina. Canadá. Québec.

Recebido: 08/01/2020

Aceito: $24 / 04 / 2020$

\section{Como citar}

CAMILLO, Everton da Silva; BOCCANFUSO, Dorothée; CASTRO FILHO, Claudio Marcondes de. Quality education for Latin American countries: analysis and contributions from the Policy on Educational Success of Québec. Em Questão, Porto Alegre, v. 26, n. 3, p. 490-514, set./dez. 2020. DOI: https://doi.org/10.19132/1808-5245263.490-514. 